\title{
Oropharyngeal Cancer pN2b TNM Finding v6 and v7
}

National Cancer Institute

\section{Source}

National Cancer Institute. Oropharyngeal Cancer pN2b TNM Finding v6 and v7. NCI

Thesaurus. Code C64611.

Oropharyngeal cancer with metastasis in two or more ipsilateral nodes, none more than $6 \mathrm{~cm}$ in greatest dimension. (from AJCC 6th and 7th Eds.) 